3 Pike MC, Henderson BE, Krailo MD, Duke A, Roy S. Breast cancer in young women and use of oral contraceptives: possible modifying effect of formulation and age at use. Lancet 1983;ii: 926-30.

4 McPherson K, Neil A, Vessey MP, Doll R. Oral contraceptives and breast cancer. Lancet $1983 ;$ ii: $1414-5$.

5 Olsson H, Olsson ML, Möller TR, Ranstam J, Holm P. Oral contraceptive use and breast cancer in young women in Sweden. Lancet 1985;i:748-9.

6 Stadel BV, Rubin GL, Webster LA, Schlesselman JJ, Wingo PA. Oral contraceptives and breast cancer in young women. Lancet 1985; ii:970-3.

7 Anonymous. Another look at the pill and breast cancer [Editorial]. Lancet 1985;ii:985-7.

8 Royal Commission of Inquiry. Contraception, sterilization and abortion in New Zealand. Wellington: Government Printer, 1977.

Mantel N, Haenszel $W$. Statistical aspects of the analysis of data from retrospective studies of disease. Fournal of the National Cancer Institute 1959;22:719-48.

10 Cornfield J. A statistical problem arising from retrospective studies. In: Neyman J, ed. Proceedings of the third Berkeley symposium on mathematical statistics and probability. Vol IV. Berkeley: University of California Press, 1956:135-48.

11 Thomas DG. Exact and asymptotic methods for the combination of $2 \times 2$ tables. Comput Biomed Res 1975;8:423-46.
12 Breslow NE, Day NE. Statistical methods in cancer research. Vol I. The analysis of case-control studies. Lyons: International Agency for Research on Cancer, 1980. (IARC Scientific Publications No 32.

13 Baker RJ, Nelder JA. The GLIM system: generalized linear interactive modelling. Oxford: Numerical Algorithms Group, 1978.

14 Vessey MP, McPherson K, Yeates D, Doll R. Oral contraceptive use and abortion before firs term pregnancy in relation to breast cancer risk. $\mathrm{Br} \mathcal{f}$ Cancer 1982;45:327-31.

15 Paffenbarger RS, Fasal E, Simmons ME, Kampert JB. Cancer risk as related to use of oral contraceptives during fertile years. Cancer 1977;39:1887-91.

6 Harris NV, Weiss NS, Francis AM, Polissar L. Breast cancer in relation to patterns of oral contraceptive use. Am f Epidemiol 1982;116:643-51.

17 Pike MC, Henderson BE, Casagrande JT, Rosario I, Gray GE. Oral contraceptive use and early abortion as risk factors for breast cancer in young women. Br $\mathcal{J}$ Cancer 1981;43:72-6.

18 McPherson K, Coope PA. Early oral contraceptive use and breast cancer risk. Lancet 1986; ;: 685-6.

19 Royal College of General Practitioners. Breast cancer and oral contraceptives: findings in Royal College of General Practitioners' study. Br Med f 1981;282:2089-93.

Accepted 9 September 1986)

\title{
Does short term placebo treatment of chronic schizophrenia produce long term harm?
}

\author{
D A CURSON, S R HIRSCH, S D PLATT, R W BAMBER, T R E BARNES
}

\begin{abstract}
A randomised double blind placebo controlled trial is the most reliable method of assessing putative new developments in medical treatment. In schizophrenia, however, some clinicians believe that relapse contributes to long term deterioration and therefore that patients exposed to either placebo or an inactive new treatment may be put at a disadvantage in the long run if the trial leads to an additional relapse. A seven year follow up of patients included in a randomised placebo controlled trial of fluphenazine decanoate, in which $66 \%$ of the group given placebo relapsed compared with $8 \%$ of those who received the active drug, permitted examination of any long term adverse consequences in those patients who had received placebo. Seventy six $(94 \%)$ of the 81 patients in the original trial were followed up. At the end of the follow up period there were no consistent or important differences in any measure of clinical or social outcome between the patients who had received placebo and those who had received the active drug. This negative finding has implications for the debate on the risk of placebo controlled trials of maintenance treatment in chronic schizophrenia.
\end{abstract}

\section{Introduction}

We set out to determine whether long term harm had resulted from fairly short term placebo treatment and a high relapse rate in the first randomised placebo controlled trial of depot neuroleptic treatment of outpatients with chronic schizophrenia. ${ }^{1}$ During that nine month trial $66 \%$ of the group given placebo relapsed compared with $8 \%$ of the group given fluphenazine decanoate. The clinical question is, What are the long term effects of a single relapse in schizophrenia? A search of previous reports failed to identify any other long term follow up studies of the effects of time limited placebo treatment accompanied by relapse in patients with schizophrenia.

The importance of the randomised double blind placebo controlled trial is well known; it is the quickest and most efficient way of determining the efficacy of an unproved treatment. In one step it eliminates the bias for a particular treatment of both patients and clinicians and bias due to the type of cases selected, placebo effects, and non-specific effects arising during the course of treatment, including the contribution of time in conditions with a tendency to remit over time.

The methods used in the original study were justified because it was not then known how much of the apparent beneficial effect of depot neuroleptics was pharmacological and how much could be attributed to the increased support and supervision provided by changes in environmental factors or in treatment style and approach that were developing.

\section{Patients and methods}

Seventy six (94\%) of the 81 patients with chronic schizophrenia who had entered the original trial were traced; four remained untraced, and one refused interview. Twelve of the 76 patients traced had died. At follow up the mental state of the 64 surviving patients was assessed with the ninth edition of the present state examination ${ }^{2}$; side effects were recorded on an extrapyramidal rating scale devised by Mindham $e t a l^{3}$ and modified by Knights $e t \mathrm{al}^{4}$; social functioning was assessed with the social behaviour assessment schedule ${ }^{5} ;$ and follow up information from case notes and general practice records was recorded on a datasheet of 66 items. A high agreement was achieved between raters on all assessment schedules during training, and this was checked during the study.

In the initial trial social functioning was assessed with a schedule that combined social behaviour and role performance. ${ }^{7}$ The problem of comparing results from different instruments was overcome by adopting a technique used by Brockington $e t a l$, in which two $100 \mathrm{~mm}$ linear analogue 
scales for occupational record and social involvement, each with six cues, were independently rated by two of us (DAC and RWB) after scrutiny of the raw data from the initial trial and follow up schedules. ${ }^{8}$ The means of the scores were taken as the social state rating. Inter-rater reliability ranged between $r=0.86(p<0.001)$ and $r=0.90(p<0.001)$, and differences in scoring between raters were symmetrically distributed.

Differences between the drug and placebo groups were tested for significance by the $\chi^{2}$ test or Mann-Whitney U test. The significance level $(\alpha)$ was set at $0 \cdot 05$.

\section{Results}

A detailed analysis of the follow up study has been reported elsewhere..$^{4 \cdot 11}$ Entry criteria and demographic variables during the trial and at follow up showed no significant differences between the drug and placebo groups. Twelve patients died during the follow up period (eight given the drug, four given placebo), four committed suicide (two given the drug, two given placebo), and one patient given placebo died of burns probably as a consequence of her illness. There was no relation between any cause of death and treatment with placebo or active drug. Of the 74 patients who completed the trial, 33 of the 38 given placebo were compared with 28 of the 36 given fluphenazine, using a wide variety of variables (table). Data were incomplete

Comparison of patients treated with fluphenazine and placebo at seven year follow up (figures are numbers $(\%)$ of patients)

\begin{tabular}{|c|c|c|c|}
\hline & & $\begin{array}{l}\text { Fluphenazine } \\
\qquad(\mathrm{n}=28)\end{array}$ & $\begin{array}{l}\text { Placebo } \\
(\mathrm{n}=33)\end{array}$ \\
\hline & & $\mathrm{No}(\%)$ & No $(\%)$ \\
\hline 1 & $\begin{array}{l}\text { Relapse during trial }\left(\chi^{2}=18 \cdot 2,1 \mathrm{df},\right. \\
\mathrm{p}<0.001\end{array}$ & $2(7)$ & $21(64)$ \\
\hline 2 & Male & $15(54)$ & $16(49)$ \\
\hline 3 & $\begin{array}{l}\text { Not living with relative or close friend } \\
\text { Diagnosis since trial ended: }\end{array}$ & $10(36)$ & $12(36)$ \\
\hline 4 & Florid & $22(79)$ & $20(61)$ \\
\hline 5 & Residual & $23(82)$ & $22(67)$ \\
\hline 6 & Episodic & $24(18)$ & $20(61)$ \\
\hline 7 & Diagnostic certainty at follow up: uncertain & & \\
\hline & or changed & $5(18)$ & $13(39)$ \\
\hline $\begin{array}{l}8 \\
9\end{array}$ & Currently not married or cohabiting & $19(68)$ & $21(64)$ \\
\hline $\begin{array}{r}9 \\
10\end{array}$ & Unemployed at follow up & $17(61)$ & $15(46)$ \\
\hline 10 & $\begin{array}{l}\text { Currently inpatient or day patient or at day } \\
\text { centre }\end{array}$ & $10(36)$ & $10(30)$ \\
\hline 11 & Taking antidepressants since trial ended & $11(39)$ & $12(36)$ \\
\hline 12 & $\begin{array}{l}\text { Injections received in clinic }<90 \% \text { of } \\
\text { time }\end{array}$ & $6(21)$ & $8(24)$ \\
\hline 13 & Fails $>1$ appointment in 10 at clinic & $13(46)$ & $12(36)$ \\
\hline 14 & Injections stopped because patient refused & $7(25)$ & $5(15)$ \\
\hline 15 & Recent alcohol abuse probable or definite & 0 & $5(15)$ \\
\hline 16 & $\begin{array}{l}\text { Outpatients with one or more subsequent } \\
\text { schizophrenic relapses }\end{array}$ & $16(57)$ & $14(42)$ \\
\hline 17 & $\begin{array}{l}\text { One or more subsequent inpatient } \\
\text { admissions (any diagnosis) }\end{array}$ & $16(57)$ & $21(64)$ \\
\hline 18 & $\begin{array}{l}\text { One or more subsequent day patient } \\
\text { admissions (any diagnosis) } \\
\text { Reason for admission: }\end{array}$ & $7(25)$ & $15(46)$ \\
\hline 19* & Florid symptoms & $13(46)$ & $20(61)$ \\
\hline $20^{\star}$ & Affective symptoms & $11(39)$ & $14(42)$ \\
\hline $21^{\star}$ & Abnormal behaviour & $12(43)$ & $10(30)$ \\
\hline $22^{\star}$ & Social reason only & $1(4)$ & $4(12)$ \\
\hline 23* & Side effects of drug & 0 & 0 \\
\hline & Relapse(s) after stopping drug: & & \\
\hline 24 & $\leqslant 3$ months & $3(15)(n=20)$ & $1(6)(n=18)$ \\
\hline 25 & 4-6 months & $4(21)(n=19)$ & $2(12)(n=17)$ \\
\hline 26 & $7-13$ months & $8(44)(n=18)$ & $7(44)(n=16)$ \\
\hline 27 & $\geqslant 14$ months & $5(46)(n=11)$ & $3(33)(n=9)$ \\
\hline & In relapse at follow up: & & \\
\hline 28 & Known to agency & $3(11)$ & $4(12)$ \\
\hline 29 & Not known to agency & $5(18)$ & $2(6)$ \\
\hline 30 & $\begin{array}{l}\text { Simple depression syndrome }(\mathrm{SD}+, \\
\mathrm{SD}++) \text { present on present state }\end{array}$ & & \\
\hline 31 & $\begin{array}{l}\text { examination } \\
\text { Deteriorated in social state rating }\end{array}$ & $\begin{array}{r}7(25) \\
23(82)\end{array}$ & $\begin{array}{r}7(22)(n=32) \\
25(78)(n=32)\end{array}$ \\
\hline & & $\operatorname{Mean}(S D)$ & $\operatorname{Mean}(S D)$ \\
\hline 32 & $\begin{array}{l}\text { Total recorded No of episodes of } \\
\text { schizophrenic illness since end of trial }\end{array}$ & $2.6(2 \cdot 0)(\mathrm{n}=27)$ & $2 \cdot 4(2 \cdot 4)(n=30)$ \\
\hline 33 & Age at follow up assessment (years) & $48 \cdot 4(10 \cdot 1)$ & $51 \cdot 2(10 \cdot 9)$ \\
\hline 34 & No of clinical relapses (outpatients) & $0.6(0.5)$ & $0.4(0.5)$ \\
\hline 35 & No of inpatient admissions since end of trial & $0.6(0.5)$ & $0.6(0.5)$ \\
\hline 36 & $\begin{array}{l}\text { No of day patient admissions since end of } \\
\text { trial }\end{array}$ & $0.3 \quad(0$. & 0.5 \\
\hline 37 & Time continuously receiving injections since & & \\
\hline & end of trial (months) & $65 \cdot 3(24 \cdot 5)$ & $64 \cdot 2(29 \cdot 2)$ \\
\hline 38 & $\begin{array}{l}\text { Score on present state examination: } \\
\text { All patients }\end{array}$ & $10 \cdot 1(9 \cdot 3)$ & $7 \cdot 9(8 \cdot 3)(n=32)$ \\
\hline 39 & Excluding those in relapse at follow up & $9 \cdot 6(9 \cdot 1)(\mathrm{n}=23)$ & $8.0(8 \cdot 5)(\mathrm{n}=30)$ \\
\hline
\end{tabular}

*Some patients were included in more than one category. for three patients. There were no significant differences in any of the 36 outcome variables between the two groups; indeed, the similarity between the groups was remarkable.

Deterioration in social functioning, as measured by the social state rating (variable 31), and other indicators of severity of illness (variables 32, 35, 37) were closely similar between the two groups, and the proportions in relapse at the time of follow up were also similar (variables 28, 29). Two patients with continuous psychosis and two who had had more than eight relapses (one treated with fluphenazine, three treated with placebo) were excluded from the analysis of social functioning as this is a meaningless concept in such severe mental illness.

\section{Discussion}

Although $66 \%$ of the patients given placebo and $8 \%$ of those given the active drug relapsed during the original trial, there were no eventual differences between the groups in any clinical or social variable measured at the end of seven years of follow up. Overall, most of the 64 patients were severely disabled at the time of the follow up assessment and continued under the care of a special maintenance clinic.

The relation between frequency of relapse, drug treatment, and social outcome discussed in our original report ${ }^{11}$ is worth reiterating as it was neither simple nor direct and has a bearing on the relevance of our negative findings to further placebo controlled maintenance trials. In the follow up of all surviving patients there was a highly significant correlation between the number of relapses and social deterioration. Antipsychotic drugs seemed to postpone relapse, and frequent relapses may perhaps have inhibited the slow improvement in social performance long after florid symptoms had been controlled by treatment. ${ }^{12}$ There was, however, no difference in the number of relapses after the end of the trial between the patients who received placebo and those who received the active drug (variable 32, table). This finding may reflect either the extent to which drugs were prescribed and treatment complied with or the severity of illness. Studies of withdrawal of antipsychotic drugs suggest that patients switched to placebo tend to relapse within a few months..$^{1314}$ Thus the absence of any difference in social outcome between the groups may partly have been due to the relatively short time for which patients were deprived of active treatment during the trial compared with the duration of the follow up period.

Alternatively, $80 \%$ of the patients had deteriorated over the seven years as assessed by social measures despite the high proportion receiving depot antipsychotic drugs and the dedicated efforts of the staff of the special maintenance clinic. In the light of this it is perhaps not surprising that none of the long term deterioration could be attributed to treatment with placebo during the trial.

There is another need for caution when interpreting our generally negative findings. Freiman et al drew attention to the danger of a type II error - that is, a false negative finding - with relatively small numbers of patients. ${ }^{15}$ It can be calculated that with two groups of 30 patients, with $\alpha$ (significance) set at 0.05 and power $(1-\beta)$ set at 0.8 , only a difference of $40 \%$ or greater would reach significance. ${ }^{16} \mathrm{With}$ our sample size the likelihood of obtaining a significant difference is not high. In an attempt to overcome this limitation, we re-examined our data for non-significant differences between the groups that were close to significance, or for trends in that direction. When we took a cut off value of $15 \%$ only nine rather heterogeneous variables emerged as showing a difference between the groups: the trend was towards the drug treated group in five and towards the placebo treated group in four. Raising the cut off point to just above a $15 \%$ difference left only two variables, with a trend towards the placebo treated group: diagnosis uncertain/changed $(21 \%)$ and day patient admissions $(21 \%)$. There was no evidence, therefore, that the results of this follow up study were biased by the patients who received flacebo injections during the original trial.

This study failed to show any long term untoward effects of a single relapse during a nine month placebo controlled trial. This result has implications for the debate on the risk of placebo controlled trials in schizophrenia in particular, and on the concept of placebo controlled trials in general. The lack of long term effects 
cannot be taken by itself as a justification for such trials. Each trial must be justified on its merits, which involve far broader issues than can be discussed here. Indeed, in the light of more than 35 studies confirming the benefits of maintenance treatment for schizophrenia the original trial would be unjustifiable if proposed today. Trials of new drugs for patients who have already relapsed would be judged on a different basis.

The follow up study was conducted at the academic unit for clinical psychopharmacology at Guy's Hospital Medical School, London. We are grateful to Dr R Gaind and Dr D Bennett; the community psychiatric nurses and medical records staff of St Olave's and St Francis hospitals; Dr A A Schiff of E R Squibb and Sons; and Mrs Carol Neale and Mrs Phyl Maskell, who typed all the drafts of the manuscript.

\section{References \\ 1 Hirsch SR, Gaind R, Rohde PD, Stevens BC, W'ing JK. Outpatient maintenance of chronic schizophrenic patients with long-acting fluphenazine: double-blind placebo trial. $\mathrm{Br}$.Med $\mathcal{J}$ $1973 ;$ i $633-7$. \\ 2 Wing JK. Cooper JE, Sartorius $\mathrm{N}$. The measurement and classification of psychiatric symptoms. Cambridge: Cambridge University Press, 1974. \\ 3 Mindham RH, Gaind R, Anstee BH. Comparison of orphenadrine and placebo on the control of phenothiazine-induced parkinsonism. Psychol.Med 1972;2:406-13 \\ 4 Knights A, Okasha MS. Salih MA, Hirsch SR. A trial of fluphenazine versus flupenthixol in maintenance of schizophrenic outpatients. Br f Psychiatry 1979;135:515-23.}

5 Platt S, Weyman A, Hirsch SR, Hewett S. The social behaviour assessment schedule (SBAS): rationale, contents, scoring and reliability of a new interview schedule. Soc Psychiatn 1980;15:43-55.

6 Platt S, Hirsch S, Wevman A. Social behaviour assessment schedule (SBAS). 3rd ed. Windsor: NFER-Nelson, 1983

7 Stevens BC. Role of fluphenazine decanoate in lessening the burden of chronic schizophrenics in the community. Psychol Med 1973;3:141-58.

8 Brockington IF, Kendell RE, Leff JP. Definitions of schizophrenia: concordance and prediction of outcome. Psychol Med 1978;8:387-98.

9 Curson DA, Barnes TRE, Bamber RW, Platt SD, Hirsch SR, Duffy JC. Long-term depot maintenance of chronic schizophrenic outpatients: the seven year follow-up of the Medical maintenance of chronic schizophrenic outpatients: the seven year follow-up of the Medical
Research Council fluphenazine placebo trial. I. Course of illness, stability of diagnosis, and the Research Council fluphenazine placebo trial. I. Course of illness, stabily
role of a special maintenance clinic. Br f Psychiatry 1985;146:464-9.

10 Curson DA, Barnes TRE, Bamber RW', Platt SD, Hirsch SR, Duffy JC. Long-term depot maintenance of chronic schizophrenic outpatients: the seven year follow-up of the Medical Research Council fluphenazine placebo trial. II. The incidence of compliance problems, sideeffects, neurotic symptoms and depression. Brf Psychiatry 1985; 146:474-80.

11 Curson DA, Barnes TRE, Bamber RW, Platt SD, HIrsch SR, Duffy JC. Long-term depot maintenance of chronic schizophrenic outpatients: the seven year follow-up of the Medical Research Council fluphenazine/placebo trial. III. Relapse postponement or relapse prevention? The implications for long-term outcome. Br $\mathcal{F}$ Psychiatr 1985;146:474-80.

12 Barnes TRE, Milavich G, Curson DA, Platt SD. Use of the social behaviour assessment schedule SBAS in a trial of maintenance antipsychotic therapy in schizophrenic outpatients: pimozide versus fluphenazine. Soc Psychiatn. 1983;18:193-9.

13 Davis JM. Overview: maintenance therapy in psychiatry. I. Schizophrenia. Am $\mathcal{F}$ Psychiatry 1975;132:1237-45.

14 Johnson DAW. Haloperidol decanoate and the treatment of chronic schizophrenia. In: Johnson DAW, ed. Therapeutics today. Vol 2. New York: Adis Press, 1982

15 Freiman JA, Chalmers TC, Smith H, Kuebler RR. The importance of beta and the type II error and sample size in the design and interpretation of the randomized control trial. $N$ Engl f Med 1978;299:690-4.

16 Fleiss JL. Statistical methods for rates and proportions. New York: Wiley, 1973:1976-94.

Accepted 28 fuly 1986

\title{
Plasminogen activators in human colorectal neoplasia
}

\author{
J S K GELISTER, M MAHMOUD, M R LEWIN, P J GAFFNEY, P B BOULOS
}

\begin{abstract}
A crucial step in the transition from adenomatous polyp to invasive colorectal cancer is the degradation of the epithelial basement membrane. Plasminogen activators may play a part in regulating the extracellular protease environment necessary for this to occur. Both functional and antigenic activity of the two principal activators of plasminogen, tissue plasminogen activator and urokinase, were measured in $\mathbf{3 0}$ colorectal cancers, matched samples of mucosa, and eight adenomatous polyps. Both polyps $(\mathbf{p}<\mathbf{0 . 0 1})$ and carcinomas $(\mathbf{p}<0.001)$ had raised urokinase activities compared with normal mucosa, the activity being highest in the carcinomas. Activity of tissue plasminogen activator, however, was diminished in both polyps $(\mathbf{p}<0.01)$ and carcinomas $(\mathbf{p}<0.001)$ compared with normal mucosa, the values being lowest in carcinomas. Plasmin generation by urokinase-in contrast with tissue plasminogen activator-is fibrin independent and thus less subject to physiological control.
\end{abstract}

Department of Surgery, University College London, The Rayne Institute, London WC1E 6JJ

J S K GELISTER, FRCS, surgical research fellow

M R LEWIN, PHD, senior research fellow

P B BOULOS, MS, FRCS, senior lecturer in surgery

National Institute of Biological Standards and Control, London NW3 6RB M MAHMOUD, MSC, senior scientific officer

P J GAFFNEY, DSC, FRCPATH, senior scientist

Correspondence to: $\mathrm{Mr}$ Gelister.
This capacity to produce urokinase may be an important factor contributing to the malignant potential of adenomatous polyps and to the invasive quality of established carcinomas.

\section{Introduction}

The generation of proteolytic enzymes, including those of the fibrinolytic system, has been implicated in the development and spread of cancer. Fibrinolytic activity results from the conversion of the proenzyme plasminogen to the active proteolytic enzyme plasmin, induced by plasminogen activators. Such activators exist in two well characterised forms-tissue plasminogen activator and urokinase-which may be distinguished immunologically and by differences in molecular weight. The principal physiological role of tissue plasminogen activator is to maintain the vascular tree free of fibrin; but a corresponding role for urokinase is less clear.

In malignant tissue plasminogen activators have been ascribed various functions by the activation of plasminogen. These include destruction of tumour associated fibrin ${ }^{1}$ and the basement membrane glycoprotein components fibronectin and laminin, as well as activation of latent collagenase. ${ }^{2}$ Aberrations in production of plasminogen activator, both qualitative and quantitative, have been associated with experimental ${ }^{3}$ and human cancer. ${ }^{4}$ Most studies of fibrinolysis in human cancer have focused on overall tissue plasminogen activator activity. ${ }^{56}$ The results, however, have been contradictory and it was not possible to distinguish urokinase from tissue plasminogen activator, as these activators have been characterised only comparatively recently. By employing indirect immunological methods, however, it has been reported that urokinase is produced by malignant colorectal tissue but not by normal mucosa, ${ }^{7}$ and this finding was supported by an immunoperoxidase study which localised urokinase in colorectal tumours but not in normal 